\title{
Placing Biebersteiniaceae, a herbaceous clade of Sapindales, in a temporal and geographic context
}

\author{
A. N. Muellner ${ }^{1,2}$, D. D. Vassiliades ${ }^{3}$, and S. S. Renner ${ }^{4}$ \\ ${ }^{1}$ Molecular Systematics Section, Jodrell Laboratory, Royal Botanic Gardens Kew, Richmond, Surrey, \\ United Kingdom \\ ${ }^{2}$ Department of Botany and Molecular Evolution, Grunelius-Moellgaard Laboratory, Research Institute \\ Senckenberg, Frankfurt, Germany \\ ${ }^{3}$ Athens, Greece \\ ${ }^{4}$ Department of Biology, University of Munich, Munich, Germany
}

Received July 21, 2006; accepted March 2, 2007

Published online: May 30, 2007

(C) Springer-Verlag 2007

\begin{abstract}
Biebersteiniaceae comprise a single genus with four species of perennial herbs occurring from central Asia to Greece. A previous molecular phylogenetic study placed one of the species in an isolated position in Sapindales, while morphological studies had placed Biebersteinia in or near Geraniaceae, albeit doubtfully. We tested the monophyly and placement of the family with data from the chloroplast genes $r b c \mathrm{~L}$ and $a t p \mathrm{~B}$ obtained for all four species, other major clades of Sapindales and outgroups for a total of up to 114 taxa. Parsimony, Bayesian, and likelihood analyses place Biebersteinia in Sapindales, possibly as sister to the other eight families. Strict and relaxed molecular clocks constrained with fossils of Biebersteinia and up to eight other Sapindales suggest that the Biebersteinia crown group diversified in the Oligocene and Miocene, while the stem lineage dates back to the Late Paleocene. Ages for other sapindalean families are earlier than those obtained in more sparsely sampled analyses, although estimates for Burseraceae agree surprisingly well. Ancestral area analyses suggest that Biebersteinia expanded from the eastern part of its range (i.e. Tibet and Inner Mongolia) to the west, although analyses are hampered by the unclear sister group relationships.
\end{abstract}

Key words: Bayesian relaxed clock, Biebersteinia, biogeography, fossil constraints, molecular clock, phylogenetics, Sapindales.

\section{Introduction}

Biebersteinia comprises four species of glandular-hairy herbs that occur in temperate mountainous regions from central Asia to Greece. Three of the species are adapted to arid or semi-arid environments, while the natural habitat of $B$. orphanidis are open patches in mid-altitude Abies and Cedrus forests in Greece and Turkey. All species have medicinal properties and are therefore utilized by local communities (Zhang et al. 1995, Farsam et al. 2000, Vassiliades and Yannitsaros 2000, Miceli et al. 2005).

When describing Biebersteinia odora, Stephan (1806) placed his new genus between Grielum (Neuradaceae) and Suriana (Simaroubaceae). Subsequent authors suggested affinities with Zygophyllaceae, Rosaceae, Geraniaceae, and Rutaceae (see Bakker et al. 
1998 for the taxonomic history of Biebersteinia). Boissier, in his Flora Orientalis (1867), placed Biebersteinia in the Geraniaceae, and other workers then followed this option. Biebersteinia, however, never fit well in Geraniaceae in having only one ovule per locule, in its pollen morphology, and in having a gynophore, and Takhtajan (1997) therefore recognized it as a separate order and family (as first suggested by Endlicher 1841). Phylogenetic analyses based on the plastid DNA markers $r b c \mathrm{~L}$ and $a t p \mathrm{~B}$ revealed that $B$. orphanidis belongs in the Sapindales, albeit in an isolated position (Bakker et al. 1998), and this result is reflected in the classifications of the Angiosperm Phylogeny Group, which rank Biebersteinia as one of the nine families of the Sapindales (APG 1998, APG II 2003).

We here test the monophyly of Biebersteinia by analyzing DNA sequences from all four species, and we also place the family in a phylogenetic, temporal, and geographic context by including a dense sample of representatives of Sapindales and information from fossils of Biebersteinia and its relatives. Specifically, we address the following questions: (1) is Biebersteinia monophyletic; (2) who are the closest relatives of Biebersteinia; and (3) what is the likely time of divergence of the Biebersteinia crown group? This last question involved performing molecular clock analyses for a large sample of Sapindales so as to include multiple fossils from as many lineages as possible.

\section{Materials and methods}

Taxon sampling. Material of Biebersteinia was collected in the field or taken from cultivated plants. $R b c \mathrm{~L}$ sequences of 84 other taxa were downloaded from GenBank (http://www.ncbi. nlm.nih.gov/) and 27 were available from the first author's previous work on Sapindales (Muellner et al. 2003, 2006). For the atpB dataset, 61 sequences were downloaded from GenBank. Besides the four species of Biebersteiniaceae, our $r b c \mathrm{~L}$ matrices include representatives of the other eight families of Sapindales (Anacardiaceae,
Burseraceae, Kirkiaceae, Meliaceae, Nitrariaceae (including Peganaceae and Tetradiclidaceae), Rutaceae, Sapindaceae, and Simaroubaceae) plus representatives of the related orders Malvales, Brassicales, Oxalidales, Geraniales, and Saxifragales (cf. Bakker et al. 1998, APG II 2003). Voucher information is given in Wikström et al. (2001) and Muellner et al. (2003, 2006). Vouchers of Biebersteinia are deposited in the following herbaria: B. heterostemon at Harvard (A; Boufford et al. 31189, Xizang, Changdu Xian, 2004); $B$. multifida and B. odora in the Herbarium Senckenbergianum (FR; Vassiliades 165, Rasjera, 2000, and Holubec s.n., Chuiskie Belkie, Altai Mts., 2005, respectively); B. orphanidis in the herbarium of the University of Reading (RNG; Vassiliades s.n., Peloponnisos, Mt. Saitas, 1997). Sample designation and GenBank accession numbers are listed in Table 1. A fifth named entity, Biebersteinia leiosepala Jaub. and Spach (Paris herbarium, $\mathrm{P}$, seen by DV), is usually considered a synonym of $B$. multifida (Knuth 1912, Schönbeck-Temesy 1970) and was not included in our study.

Isolation of DNA, amplification and sequencing. Leaf fragments were dried in silica gel prior to DNA extraction or taken from herbarium vouchers. Total DNA was extracted following the cetyltrimethyl-ammonium bromide (CTAB) procedure of Doyle and Doyle (1987), except that after precipitation with isopropanol and subsequent centrifugation, the DNA pellet was washed with $70 \%$ ethanol, dried at $37^{\circ} \mathrm{C}$, and resuspended in TRIS-EDTA (TE) buffer. Samples were purified on caesium chloride/ethidium bromide gradients. For $B$. heterostemon, DNA was extracted using a NucleoSpin ${ }^{\circledR}$ Plant kit (Macherey-Nagel, Dueren, Germany). $R b c \mathrm{~L}$ was amplied with the primers $1 \mathrm{~F}$, 636F, 724R, and 1326R (Olmstead et al. 1992, Fay et al. 1998) and $a t p \mathrm{~B}$ with the primers $2 \mathrm{~F}, 611 \mathrm{~F}$, 766R, and 1494R (Hoot et al. 1995). A 50- $\mu \mathrm{l}$ reaction mix contained $45 \mu$ l ReddyMix polymerase chain reaction (PCR) mastermix at $2.5 \mathrm{mM}$ $\mathrm{MgCl}_{2}$ concentration (ABgene, Epsom, Surrey, UK), $1 \mu \mathrm{l}$ of two primers each (10pmol), $1 \mu \mathrm{l}$ template DNA, and $2 \mu \mathrm{l}$ bovine serum albumin (BSA; 0.4\%). Initial denaturation was $3 \mathrm{~min}$ at $95^{\circ} \mathrm{C}$, followed by one cycle of denaturation for $1.5 \mathrm{~min}$ at $95^{\circ} \mathrm{C}$, annealing for $1 \mathrm{~min}$ at $45^{\circ} \mathrm{C}$ and extension for $1 \mathrm{~min}$ at $72^{\circ} \mathrm{C}$, followed by 36 cycles of denaturation for $1 \mathrm{~min}$ at $95^{\circ} \mathrm{C}$, annealing for $1 \mathrm{~min}$ at $48^{\circ} \mathrm{C}$, and extension for $1 \mathrm{~min}$ at $72^{\circ} \mathrm{C}$; 
Table 1. Taxa and classification for the material used in this study. Family circumscription follows APG II (2003). All sequences are available from GenBank; new sequences have the accession numbers DQ408665DQ408667 and EF431913-EF431915 (http://www.ncbi.nlm.nih.gov/)

\begin{tabular}{|c|c|c|c|}
\hline Order/Family & Species & $\begin{array}{l}\text { GenBank } \\
\text { no. } r b c \mathrm{~L}\end{array}$ & $\begin{array}{l}\text { GenBank } \\
\text { no. atpB }\end{array}$ \\
\hline \multicolumn{4}{|l|}{ Sapindales } \\
\hline \multirow[t]{27}{*}{ Meliaceae } & Aglaia elaeagnoidea Benth. & AY128209 & \\
\hline & Aphanamixis polystachya (Wall.) R.N. Parker & AY 128213 & \\
\hline & Azadirachta indica A. Juss. & AY 128215 & \\
\hline & Capuronianthus mahafalensis Leroy & AY128218 & \\
\hline & Carapa guianensis Aubl. & AY128219 & \\
\hline & Cedrela odorata $\mathrm{L}$. & AY 128220 & \\
\hline & Chisocheton macrophyllus King & AY128221 & \\
\hline & Chukrasia tabularis A. Juss. & AY128223 & \\
\hline & Cipadessa baccifera Miq. & AY128224 & \\
\hline & Dysoxylum gaudichaudianum (A. Juss.) Miq. & AY 128227 & \\
\hline & Ekebergia capensis Sparrm. & AY 128228 & \\
\hline & Guarea glabra Vahl & AY 128229 & \\
\hline & Khaya anthotheca C.DC. & AY 128231 & \\
\hline & Lansium domesticum Correa & AY 128232 & \\
\hline & Lovoa swynnertonii E.G. Baker & AY 128233 & \\
\hline & Melia azedarach $\mathrm{L}$. & AY 128234 & \\
\hline & Munronia pinnata (Wall.) Theob. & AY 128236 & \\
\hline & Naregamia alata Wight \& Arn. & DQ238059 & \\
\hline & Nymania capensis Lindb. & AY 128238 & AF066855 \\
\hline & Quivisianthe papinae Baill. & AY128239 & \\
\hline & Ruagea pubescens Karst. & DQ238057 & \\
\hline & Sandoricum cf. koetjape (Burm. f.) Merr. & DQ238068 & \\
\hline & Swietenia macrophylla King & AY128241 & AJ235616 \\
\hline & Toona sp. & AY 128243 & \\
\hline & Trichilia emetica Vahl & AY128244 & AJ 235629 \\
\hline & Turraea sericea $\mathrm{Sm}$. & AY128245 & \\
\hline & Vavaea amicorum Benth. & DQ238066/67 & \\
\hline \multirow[t]{4}{*}{ Simaroubaceae } & Ailanthus altissima (Mill.) Swingle & AY 128247 & AF035895 \\
\hline & Quassia amara $\mathrm{L}$. & AY 128250 & \\
\hline & Simarouba glauca DC. & AY 128252 & AF235602 \\
\hline & Soulamea soulameoides (A. Gray) Noot. & U38923 & \\
\hline \multirow[t]{11}{*}{ Rutaceae } & Adenandra uniflora Willd. & AF066803 & AF066832 \\
\hline & Aegle marmelos (L.) Correa ex Roxb. & AF066811 & AF066839 \\
\hline & Atalantia ceylanica (Arn.) Oliver & AF066812 & AF066840 \\
\hline & Calodendrum capensis Thunb. & AF066805 & AF066834 \\
\hline & Casimiroa edulis La Llave & AF066808 & AF066837 \\
\hline & Chloroxylon swietenia DC. & AF066802 & AF066831 \\
\hline & Choisya mollis Standley & AF066800 & AF066829 \\
\hline & Chorilaena quercifolia Endl. & AF066810 & AF066838 \\
\hline & Citrus glauca (Lindl.) I.H. Burkill & AF066819 & \\
\hline & Citrus japonica Swingle & AF066799 & \\
\hline & Citrus trifoliata $\mathrm{L}$. & AJ235806 & \\
\hline
\end{tabular}


Table 1. (Continued)

\begin{tabular}{|c|c|c|c|}
\hline Order/Family & Species & $\begin{array}{l}\text { GenBank } \\
\text { no. } r b c \mathrm{~L}\end{array}$ & $\begin{array}{l}\text { GenBank } \\
\text { no. atpB }\end{array}$ \\
\hline & Clausena excavata Burm. f. & AF066813 & AF066841 \\
\hline & Cneorum pulverulentum Vent. & U38858 & AF066828 \\
\hline & Correa pulchella J.B. Mackay ex Sweet & AF066816 & AF066844 \\
\hline & Dictamnus sp. & AF066801 & AF066830 \\
\hline & Diplolaena dampieri Desf. & AF066807 & AF066836 \\
\hline & Eriostemon brevifolius A. Cunn. ex Endl. & AF156882 & AF156882 \\
\hline & Flindersia australis $\mathrm{R} . \mathrm{Br}$. & U38861 & \\
\hline & Glycosmis pentaphylla (Retz.) DC. & AF066820 & \\
\hline & Harrisonia perforata (Blanco) Merr. & U38863 & \\
\hline & Lunasia amara Blanco & AF066814 & AF066842 \\
\hline & Melicope ternata J.R. Forst. \& G. Forst. & AF 116271 & AF066826 \\
\hline & Phebalium woombye (Bailey) Domin & AF066822 & AF066852 \\
\hline & Phellodendron amurense Rupr. & AF066804 & AF066833 \\
\hline & Pilocarpus pennatifolius Lem. & AF066809 & AF066825 \\
\hline & Pleiospermium alatum Wight \& Arn. & AF066821 & AF066850 \\
\hline & Ptaeroxylon obliquum (Thunb.) Radlk. & AF 123276 & AF066848 \\
\hline & Ruta graveolens $\mathrm{L}$. & AY128251 & AF035913 \\
\hline & Sarcomelicope simplicifolia (Endl.) T.G. Hartley & AF066817 & AF066845 \\
\hline & Severinia buxifolia (Poir.) Tenore & AF066806 & AF066835 \\
\hline & Skimmia anquetilia N.P. Taylor \& H.K. Airy Shaw & AF066818 & AF066846 \\
\hline & Spathelia excelsa Krause & AF066798 & AF066854 \\
\hline & Zanthoxylum monophyllum (Lam.) P. Wilson & ZMU39282 & \\
\hline & Zanthoxylum sp. & & AF066843 \\
\hline \multirow[t]{2}{*}{ Burseraceae } & Bursera inaguensis Britton & L01890 & AF035899 \\
\hline & Canarium ovatum Engl. & U38856 & \\
\hline \multirow[t]{9}{*}{ Anacardiaceae } & Blepharocarya depauperata Specht & U38928 & \\
\hline & Buchanania latifolia Roxb. & U39275 & \\
\hline & Cyrtocarpa procera Knuth & U39272 & \\
\hline & Mangifera indica $\mathrm{L}$. & U39269 & \\
\hline & Pistacia vera $\mathrm{L}$. & AJ 235786 & AJ132282 \\
\hline & Rhus copallina $\mathrm{L}$. & U00440 & AF035912 \\
\hline & Schinus molle L. & U39270 & AF035914 \\
\hline & Spondias cytherea Sonn. & U39274 & \\
\hline & Tapirira mexicana Marchand & U39273 & \\
\hline Kirkiaceae & Kirkia wilmsii Engl. & U38857 & \\
\hline \multirow[t]{6}{*}{ Sapindaceae } & Acer saccharum L. & L01881 & AF035893 \\
\hline & Aesculus pavia Castigl. & U39277 & AF035894 \\
\hline & Allophyllus cobbe (L.) Reusch & AY 128248 & \\
\hline & Cupaniopsis anacardioides (A. Rich.) Radlk. & L13182 & AF035903 \\
\hline & Harpullia arborea (Blanco) Radlk. & AY128249 & \\
\hline & Koelreuteria paniculata Laxm. & U39283 & AJ 235513 \\
\hline Biebersteiniaceae & Biebersteinia heterostemon Maxim. & DQ408667 & EF431915 \\
\hline
\end{tabular}


Table 1. (Continued)

\begin{tabular}{|c|c|c|c|}
\hline & $\begin{array}{l}\text { Biebersteinia multifida DC. } \\
\text { Biebersteinia odora } \text { Stephan } \\
\text { Biebersteinia orphanidis Boiss. }\end{array}$ & $\begin{array}{l}\text { DQ4086665 } \\
\text { DQ408666 } \\
\text { AF035920 }\end{array}$ & $\begin{array}{l}\text { EF431913 } \\
\text { EF431914 } \\
\text { AF035921 }\end{array}$ \\
\hline Nitrariaceae & $\begin{array}{l}\text { Malacocarpus crithmifolius (Retz.) Fisch. \& C.A. Mey. } \\
\text { Peganum harmala L. } \\
\text { Tetradiclis tenella Litwinow } \\
\text { Nitraria retusa (Forssk.) Asch }\end{array}$ & $\begin{array}{l}\text { U39280 } \\
\text { U39279 } \\
\text { AJ403009 } \\
\text { U39278 }\end{array}$ & \\
\hline $\begin{array}{l}\text { Malvales } \\
\text { Bixaceae }\end{array}$ & Bixa orellana $\mathrm{L}$. & Y15139 & AF035897 \\
\hline Malvaceae & $\begin{array}{l}\text { Bombax buonopozense P. Beauv. } \\
\text { Gossypium hirsutum Cav. } \\
\text { Ochroma pyramidale (Cav. ex Lam.) Urb. } \\
\text { Thespesia populnea Sol. ex Correa }\end{array}$ & $\begin{array}{l}\text { AF022118 } \\
\text { M77700 } \\
\text { AJ233118 } \\
\text { L01961 }\end{array}$ & $\begin{array}{l}\text { AJ } 233051 \\
\text { AJ } 233063 \\
\text { AF035910 }\end{array}$ \\
\hline Cistaceae & $\begin{array}{l}\text { Cistus revolii H.J.Coste \& Soulie } \\
\text { Helianthemum grandiflorum DC. }\end{array}$ & $\begin{array}{l}\text { Y15140 } \\
\text { Y15141 }\end{array}$ & $\begin{array}{l}\text { AF035902 } \\
\text { AF035907 }\end{array}$ \\
\hline Dipterocarpaceae & Anisoptera marginata Korth. & Y15144 & AF035918 \\
\hline Muntingiaceae & Muntingera calabra $\mathrm{L}$. & Y15146 & AJ233068 \\
\hline $\begin{array}{l}\text { Brassicales } \\
\text { Brassicaceae }\end{array}$ & Capparis spinosa $\mathrm{L}$. & AY167985 & AF035900 \\
\hline Tovariaceae & Tovaria pendula Ruiz \& Pav. & M95758 & \\
\hline Limnanthaceae & Floerkea prsoerpinicoides Willd. & L12679 & AF035904 \\
\hline Bataceae & Batis maritima $\mathrm{L}$. & L22438 & AF209538 \\
\hline Caricaceae & Carica papaya $\mathrm{L}$. & M95671 & AF035901 \\
\hline Tropaeolaceae & Tropaeolum majus $\mathrm{L}$. & L14706 & AF035917 \\
\hline $\begin{array}{l}\text { Oxalidales } \\
\text { Cunoniaceae }\end{array}$ & Eucryphia lucida (Labill.) Baill. & L01918 & AF209584 \\
\hline $\begin{array}{l}\text { Geraniales } \\
\text { Geraniaceae }\end{array}$ & $\begin{array}{l}\text { Erodium variabile A.C. Leslie } \\
\text { Geranium cinereum Boiss. \& Reut. Ex Willk. \& Lange } \\
\text { Hypseocharis sp. } \\
\text { Monsonia emarginata L'Hér. } \\
\text { Pelargonium exstipulatum L'Hér. } \\
\text { Pelargonium cotyledonis L'Hér. }\end{array}$ & $\begin{array}{l}\text { L14694 } \\
\text { L14695 } \\
\text { L14699 } \\
\text { L14701 } \\
\text { L14704 }\end{array}$ & $\begin{array}{l}\text { AF093373 } \\
\text { AF209632 } \\
\text { AF035911 }\end{array}$ \\
\hline Melianthaceae & Greyia radlkoferi Szyszyl. & L11185 & AF209594 \\
\hline $\begin{array}{l}\text { Saxifragales } \\
\text { (outgroup) }\end{array}$ & $\begin{array}{l}\text { Heuchera micrantha Douglas } \\
\text { Itea virginia } \mathrm{L} \text {. }\end{array}$ & $\begin{array}{l}\text { L01925 } \\
\text { L11188 }\end{array}$ & $\begin{array}{l}\text { AF093399 } \\
\text { AF093383 }\end{array}$ \\
\hline
\end{tabular}


final extension for $10 \mathrm{~min}$ at $72^{\circ} \mathrm{C}$. Alternatively, the $r b c \mathrm{~L}$ gene was amplified in two overlapping fragments, with an initial denaturation for $2 \mathrm{~min}$ at $94^{\circ} \mathrm{C}$, followed by 28 cycles of denaturation for $1 \mathrm{~min}$ at $94^{\circ} \mathrm{C}$, annealing for $30 \mathrm{~s}$ at $48^{\circ} \mathrm{C}$ and extension for $1 \mathrm{~min}$ at $72^{\circ} \mathrm{C}$; final extension for $7 \mathrm{~min}$ at $72^{\circ} \mathrm{C}$. PCR products were cleaned using a NucleoSpin ${ }^{\circledR}$ Extract II kit (Macherey-Nagel, Dueren, Germany). Sequencing reactions were run on an ABI 3100 capillary sequencer or a $\mathrm{CEQ}^{\mathrm{TM}} 8800$ Genetic Analysis System (Beckman Coulter, Krefeld, Germany), following the manufacturer's protocols.

Sequence editing and alignment. Editing and assembly of the complementary strands were carried out with Autoassembler version 1.4.0 $(\mathrm{ABI})$, SeqMan ${ }^{\mathrm{TM}}$ II version 5.07 (Lasergene, DNASTAR, Inc., Madison, WI, USA), and DNA STRIDER version 1.2 (Christian Marck, CEA Commissariat à L'énergie atomique/Saclay, France). Alignment of $r b c \mathrm{~L}$ and $a t p \mathrm{~B}$ sequences was performed by eye. Matrices and trees have been deposited in TreeBASE (Sanderson et al. 1994) and new sequences in GenBank (http:// www.ncbi.nlm.nih.gov/).

Phylogenetic analyses. Individual and combined maximum parsimony (MP) analyses of the $r b c \mathrm{~L}$ and $a t p \mathrm{~B}$ datasets were performed using PAUP*4.0b10 (Swofford 2002). Substitutions at each nucleotide position were treated as independent, unordered, multi-state characters of equal weight (Fitch parsimony; Fitch 1971). Heuristic searches were performed using 1000 random additions of taxa, DELTRAN character state optimization, tree bisection-reconnection (TBR) branch swapping, and the option MulTrees (keeping multiple, shortest trees). For tree searches from $r b c \mathrm{~L}$, we held only 10 trees per replicate (Salamin et al. 2003). Following the 1000 replicates, we used the shortest trees found as starting trees for a swapping-to-completion search (but with a tree limit of 10000). Robustness of clades was estimated using bootstrapping (Felsenstein 1985) with 1000 replicates, using simple sequence addition, TBR branch swapping, and MulTrees, again holding 10 trees per replicate. We consider $75-84 \%$ bootstrap values moderate support and $85-100 \%$ strong support.

Maximum likelihood (ML) analyses were performed with RAxML version 2.2.1 (Stamatakis 2006; http://icwww.epfl.ch/ ${ }^{\text {stamatak/index-Dateien }}$
/Page443.htm) and Bayesian analyses with $\mathrm{MrBa}-$ yes version 3.1.2 (Ronquist and Huelsenbeck 2003; http://mrbayes.csit.fsu.edu/). The substitution models employed in these analyses were found using Modeltest version 3.06 (Posada and Crandall 1998; http://darwin.uvigo.es/software/ modeltest.html), which indicated the general time reversible model as best fitting our data with a proportion of invariable sites and a gamma shape parameter alpha to model rate heterogeneity (GTR $+\mathrm{I}+\mathrm{G})$. For the Bayesian analyses, model parameters were estimated directly during runs, using four simultaneous chains and three million cycles $(r b c \mathrm{~L})$ or one million cycles $(a t p \mathrm{~B}, r b c \mathrm{~L} /$ $a t p \mathrm{~B})$, sampling one tree every 100 generations. Trees that preceded the stabilization of the likelihood value were excluded, and the remaining trees were used to calculate posterior probabilities via the construction of a majority rule consensus tree in PAUP. For the ML searches we employed the GTR + G model, using 25 rate categories (instead of four as used in the Bayesian analyses), this being the only model implemented in RAxML.

Divergence time estimation. A likelihood-ratio test (LRT) rejected the null hypothesis of rate constancy for $r b c \mathrm{~L}$, and we therefore employed non-parametric rate smoothing (NPRS; Sanderson 1997) as implemented in TreeEdit version 1.0-a4.61 (Rambaut and Charleston 2000; http://evolve. zoo.ox.ac.uk/software.html?id $=$ TreeEdit) or a relaxed Bayesian clock approach as implemented in the multidivtime program of Thorne and Kishino (2002; http://statgen.ncsu.edu/thorne/). Standard deviations on the NPRS estimates were calculated by reapplying NPRS to 100 bootstrapped matrices.

The input topology for the Bayesian time estimation was the $r b c \mathrm{~L}$ ML tree for 80 representative Sapindales obtained with RAxML. The only substitution model implemented in multidivtime is the F84 + G model, and parameter values under this model were estimated with PAML's baseml version 3.14 (Yang 1997; http://abacus.gene.ucl.ac.uk/ software/paml.html). Thorne's program estbranches was then used to calculate branch lengths and their variance, given the sequence data $(80$ $r b c \mathrm{~L}$ sequences of a length of $1387 \mathrm{nt}$ ), the model parameter values from PAML, and the specified rooted topology. Branch lengths from estbranches became the priors for mcmc searches in multidivtime that sought to find the most likely model of rate change (with rate change assumed to be 
log-normally distributed), given the topology, time constraints on nodes (below), and a Brownian motion parameter $(v)$ that controls the magnitude of autocorrelation per million years (my) along the descending branches of the tree. Prior gamma distributions on parameters of the relaxed clock model were as follows: the mean and SD of the prior distribution for the root age were set to 100 my, based on fossils (below). The mean and SD of the prior distribution for the ingroup root rate were set to 0.0003 substitutions/site/my by dividing the median of the distances between the ingroup root and the tips by $100 \mathrm{my}$. The prior and SD for $v$ were set to 0.01 , following Thorne's manual's recommendation that the time between root and tips multiplied by $v$ be about 1 . Markov chains in multidivtime were run for 1 million generations, sampling every 100th generation for a total of 10,000 trees, with a burn-in of 10,000 generations before the first sampling of the Markov chain. To check for convergence, we ran two analyses of different chain lengths. We also tested the effect of the root rate by running one analysis with a rate of 0.0004 , one with a rate of 0.0003 .

Likelihood ratio tests are very sensitive to rate variation and may overreject the clock (Sanderson 1998). We therefore evaluated the estimates obtained from NPRS and the Bayesian relaxed clock against a strict clock model. Branch lengths were calculated in PAUP under GTR $+\mathrm{I}+\mathrm{G}$ with the clock assumption enforced, using the same ML topology as used for the relaxed clock.

Constraints and calibrations. Absolute time estimates in the Bayesian approach were obtained by simultaneously constraining nine nodes (numbered 1-9 below), for the NPRS clock and the strict clock we alternatively constrained two nodes (numbers 3 and 4 below; Table 2).

1) The root node of our dataset (i.e. the most recent common ancestor of Geraniales and Oxalidales) was constrained to maximally 137 my old, based on the onset of angiosperm radiation (Hughes 1994, Brenner 1996).

2) The divergence between Acer and Aesculus was constrained to minimally 63 my old, based on fossil fruits of the sister group of Acer, Dipteronia brownii from the Late Paleocene of Wyoming (McClain and Manchester 2001; the fruits of Dipteronia and Acer are distinct among angiosperms and different from each other).
3) The crown group of Biebersteinia was constrained to minimally 54.8 my old, based on fossil pollen from the Neomugen Formation of Inner Mongolia (Late Paleocene, 57.0-54.8 million years). This pollen has been assigned to $B$. heterostemon on the basis of the structure of its colpi and pores (Song et al. 2004; W.-M. Wang, Chinese Academy of Sciences, personal communication, 2007).

4) The crown group of Simaroubaceae were constrained to minimally 52 my old, based on fossil fruits of Ailanthus, which are distinct in their samaroid mericarps with a centrally placed seed. According to molecular phylogenetic evidence, Ailanthus is sister to the rest of Simaroubaceae (Fernando et al. 1995, Chase et al. 1999). The fossil $A$. confucii is thought to be related to the extant $A$. altissima (Corbett and Manchester 2004), which is the species included in our DNA analyses.

5) The crown group of Cedreleae were constrained to minimally 49 my old, based on fruit and seed fossils of Toona from the London Clay (Reid and Chandler 1933, DeVore et al. 2005). Since these specimens share morphological features of both modern Toona and Cedrela (T. D. Pennington, RBGK, personal communication, 2005), we alternatively used these fossils to constrain the minimum age of the stem of Cedreleae.

6) The divergence between Allophyllus and Cupaniopsis was constrained to minimally 33.7 my old, based on leaves of Allophyllus from the Eocene Green River Formation of Colorado (MacGinitie 1969; leaf matching in Allophyllus is problematic, however; M. Harrington, personal communication, 2007).

7) The crown group of Trichilieae plus Turraeeae was constrained to minimally 33.7 my old, based on fossil leaves of Trichilia from the Eocene Florissant Flora of Colorado (MacGinitie 1953, however, these fossils require further study, S. Manchester, personal communication, 2007).

8) The crown group comprising Guareae and Aglaieae was constrained to minimally $23.8 \mathrm{my}$ old, based on fossil pollen of Guarea from the Oligocene San Sebastian Formation in northern Puerto Rico (Graham and Jarzen 1969).

9) The clade uniting Chisocheton and Aglaia was constrained to minimally 5.3 my old, based on Miocene fossil wood of Chisocheton 
A. N. Muellner et al.: Biebersteinia and Sapindales

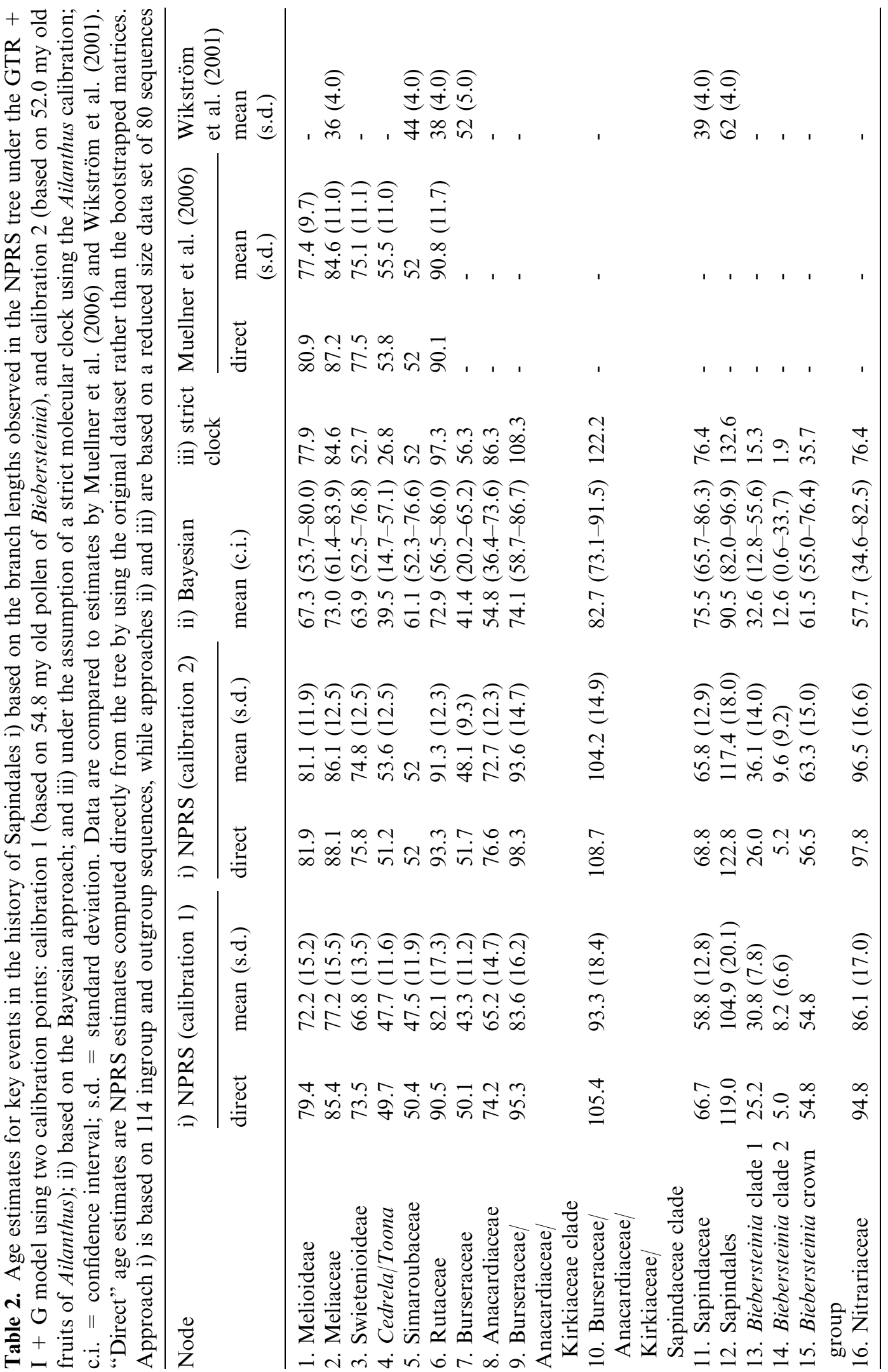


(Chisochetonoxylon) from the Tertiary beds of the Birbhum District in West Bengal (Ghosh and Roy 1979).

For absolute ages we relied on the geologic time scale of Palmer and Geissman (1999).

Ancestral area analyses. Besides considering tree topology and the distribution of fossils, we inferred the ancestral area of Biebersteiniaceae with an area-based biogeographic approach (ancestral area analysis; Bremer 1992) and an event-based approach (dispersal vicariance analysis, DIVA; http://www.ebc.uu.se/systzoo/research/diva/diva.html; Ronquist 1996, 1997). Based on the geological history of the relevant regions and the extant distribution of Biebersteinia, we defined eight areas (Fig. 1): (A) Eastern Tibetan plateau including the Hengduan Mountains (EAST TIB HENG); (B) Eastern Himalaya (EAST HIM); (C) Western Himalaya, Karakoram, Pamir, Tien Shan, Alatau, and Altai mountain ranges (WEST HIM); (D) Dzungaria and western Tien Shan (DZUN); (E) Semi-arid mountainous regions to the west, including the northern Baluchistan, Turkestanian, part of Turanian and Armeno-Iranian floristic provinces of Takhtajan (1986) (SEM-AR MOUN); (F) Mountains near the southeastern Mediterranean coast (SE MED COAST); (G) Taurus mountains in
Asia minor (TAUR MOUN); and (H) Mountains of Peloponnisos in the southern Balkan peninsula (SOUTH BALK PEN).

\section{Results}

Phylogeny estimation. Parsimony statistics for all three datasets $(r b c \mathrm{~L}, a t p \mathrm{~B}, r b c \mathrm{~L} / a t p \mathrm{~B})$ are summarized in Table 3. To the extent that taxon sampling overlapped, topologies of trees obtained with parsimony, Bayesian inference, and Maximum Likelihood were nearly identical (compare Figs. 2-5). Figure 2 shows the Bayesian tree obtained from $r b c \mathrm{~L}$ sequences of 112 ingroup and two outgroup taxa, based on 30000 total trees and a burn-in of 2880 trees Figure 5 shows the Bayesian tree obtained from combined $r b c \mathrm{~L}$ and $a t p \mathrm{~B}$ sequences of 62 ingroup and two outgroup taxa, based on 10000 total trees and a burn-in of 1060 trees.

Divergence time estimation. Table 2 summarizes all divergence time estimates (and their errors or confidence intervals) obtained with the different clock approaches, and Figs. 3 and 4 show NPRS and Bayesian chronograms. NPRS analyses using a 54.8-my minimum age

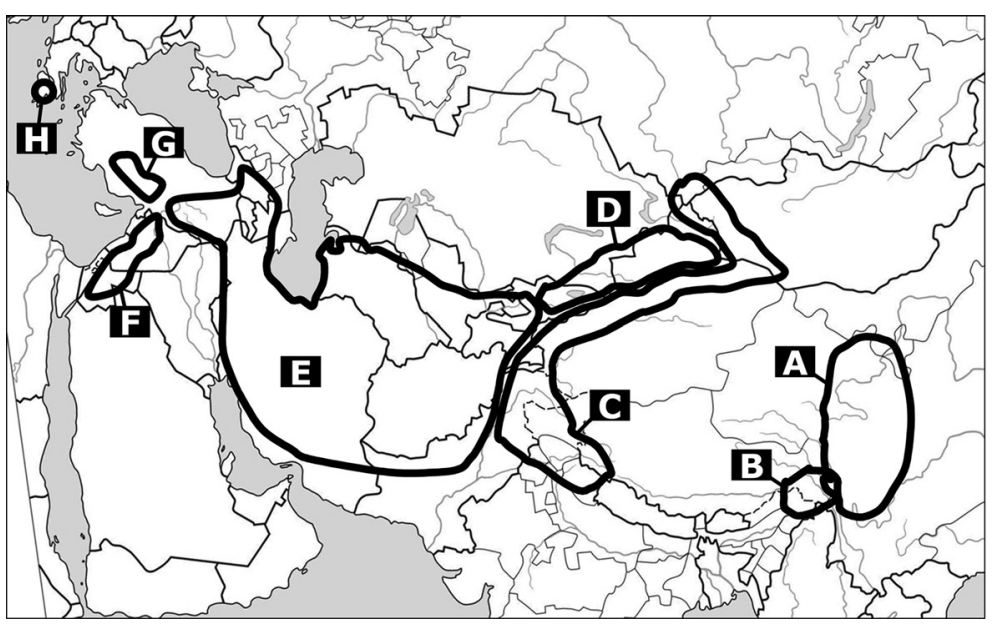

Fig. 1. Areas defined for the ancestral area analyses, based on the geological history of the area of occurrence and the extant distribution of the four species of Biebersteinia. The areas are: $A$ Eastern Tibetan plateau including the Hengduan Mountains; $B$ Eastern Himalaya; $C$ Western Himalaya, Karakoram, Pamir, Tien Shan, Alatau, and Altai mountain ranges; $D$ Dzungaria and western Tien Shan; $E$ Semi-arid mountainous regions to the west, including the northern Baluchistan, Turkestanian, part of Turanian and Armeno-Iranian floristic provinces of Takhtajan (1986); $F$ Mountains near the southeastern Mediterranean coast; $G$ Taurus mountains in Asia minor; $H$ Mountains of Peloponnisos in the southern Balkan peninsula 
Table 3. Statistics for the parsimony analyses

\begin{tabular}{llll}
\hline Data set & $r b c \mathrm{~L}$ & $a t p \mathrm{~B}$ & $r b c \mathrm{~L} / a t p \mathrm{~B}$ \\
\hline Number of taxa & 114 & 64 & 64 \\
Characters included & 1387 & 1491 & 2878 \\
Variable characters & 557 & 545 & 1030 \\
Parsimony-informative characters & 391 & 362 & 703 \\
Length of shortest tree (no. of steps) & 2180 & 1507 & 3059 \\
Shortest trees & $>10000$ & 510 & 122 \\
Consistency index & 0.31 & 0.42 & 0.39 \\
Retention index & 0.70 & 0.67 & 0.67 \\
\hline
\end{tabular}

for the Biebersteinia crown group (Fig. 3) and a 52-my minimum age for Ailanthus yielded estimates for Meliaceae and Rutaceae similar to previous estimates based on a smaller set of $r b c L$ sequences (Muellner et al. 2006). Age estimates by Wikström et al. (2001) for these families are much lower (Table 2). Bayesian and strict clock approaches gave similar results to those obtained with NPRS, except for a few cases, such as the age of Sapindales and Nitrariaceae (see Table 2). With Ailanthus used for calibration, the NPRS-based age estimate for the Biebersteinia crown group (56.5 my; Table 2) was slightly older than the oldest Biebersteinia pollen (54.8 my); with Biebersteinia used for calibration, Ailanthus was estimated as slightly younger (50.4 my) than its oldest fossils (52 my). The Bayesian clock yielded an even older estimate (61.5 my) for the Biebersteinia crown group, while the strict clock yielded a younger estimate (35.7 my; Table 2).

Ancestral area analyses. Table 4 summarizes the results of the ancestral area analysis that used the approach of Bremer (1992). A high gain/loss $(G / L)$ ratio indicates a high probability that a geographic region was part of the ancestral area. Based on this measure, the eastern Tibetan plateau, the Hengduan Mountains (area A), Dzungaria, and western (fide legend) Tien Shan (area D) likely were part of the ancestral area of Biebersteiniaceae. In DIVA, we used the "maxareas" option to impose a constraint on the number of regions allowed in ancestral distributions. With this constraint, the ancestral region inferred was the same as with the Bremer analysis.

\section{Discussion}

Our study (1) confirms that Biebersteinia is a member of Sapindales; (2) provides evidence for the monophyly of Biebersteinia; (3) suggests that the family crown group diversified in the Oligocene and Miocene; and (4) makes it likely that an area comprising the eastern Tibetan plateau, including the Hengduan Mountains, Dzungaria, Tien Shan, and eastern and western Himalayan and Altai mountain ranges as well as Inner Mongolia was the ancestral area of Biebersteinia. (5) In addition, our age estimates for Sapindales suggest that previous studies may have underestimated ages for some of the family crown groups.

Biebersteinia - phylogenetic position among Eurosid II orders. Although the molecular data of Bakker et al. (1998) provided evidence of a sapindalean rather than geranialean affinity of Biebersteinia, their analysis included

Fig. 2. Bayesian tree obtained from $r b c \mathrm{~L}$ sequences of 112 ingroup and two outgroup taxa. Capital letters A-H after Biebersteinia species names refer to the areas defined in the biogeographical analysis and shown in Fig. 1. Numbers above branches are Bayesian posterior probabilities, numbers below branches are bootstrap values (1000 replicates; italicized). Families and orders after APG II (2003) 


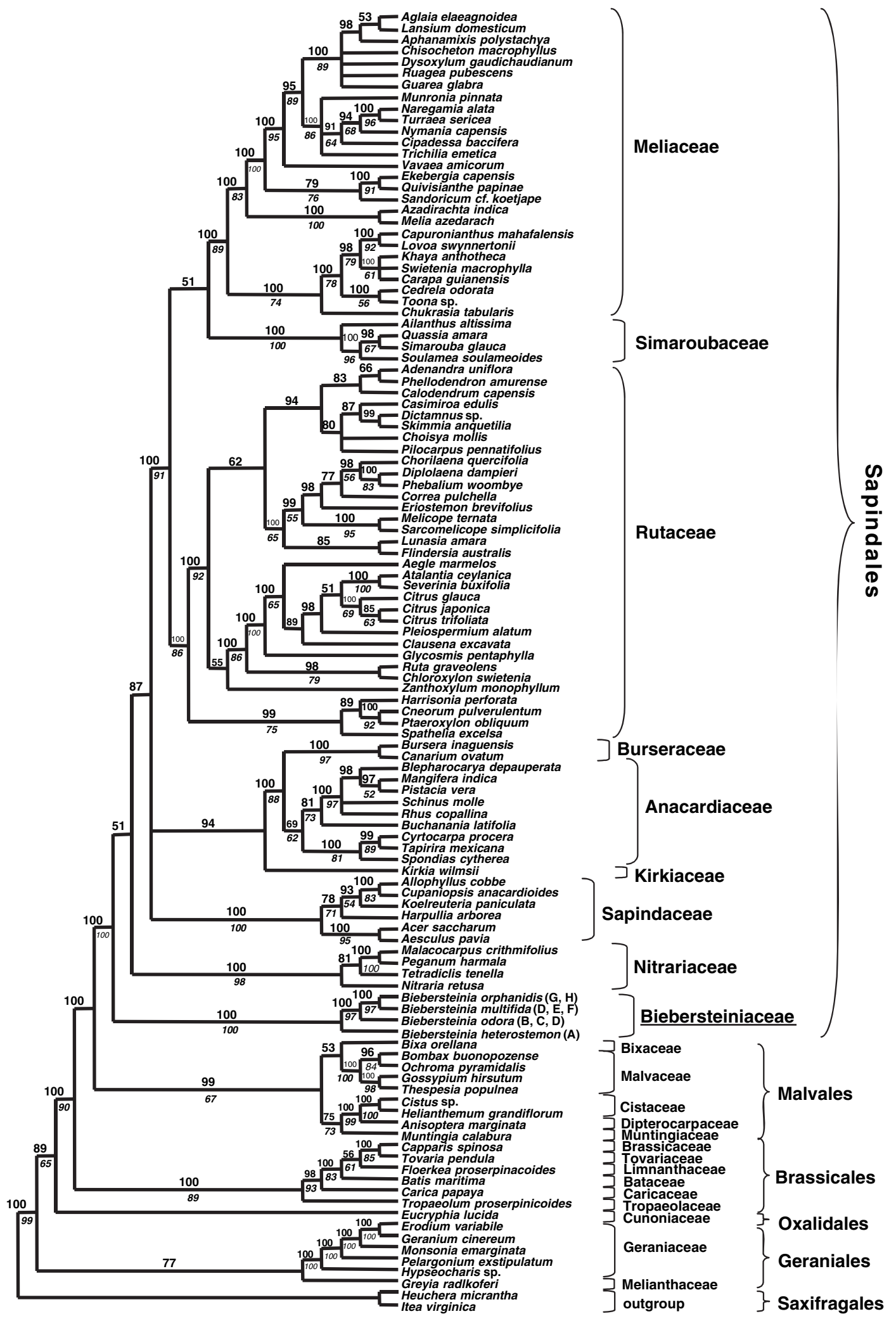


Fig. 3. NPRS chronogram based on a parsimony tree obtained from the $r b c L$ data set used in Fig. 2 and calibrated with the Biebersteinia crown group set to 54.8 my. Nodes labelled 1-16 refer to locations in the tree for which age estimates are summarized in Table 2. A, B Fruits of Ailanthus confucii, Fossil Butte, Wyoming, USA, Green River Formation, Early Eocene, c. 52 my (Corbett and Manchester 2004). C, D Pollen of Biebersteinia heterostemon, Neomugen Formation, Inner Mongolia, China, Late Paleocene, c. 54.8 my (Song et al. 2004). Numbers along the bars indicate million years. $J=$ Jurassic, $C=$ Cretaceous, $P a=$ Paleocene, $E=$ Eocene, $O=$ Oligocene, $M=$ Miocene, $P=$ Pliocene to present

Table 4. Estimation of the ancestral areas for Biebersteinia (Sapindales) applying Bremer's (1992) ancestral area analysis. $G=$ number of implied gains under forward Camin-Sokal parsimony. $L=$ number of implied losses under reverse Camin-Sokal parsimony

\begin{tabular}{llll}
\hline Areas & $G$ & $L$ & $G / L$ \\
\hline Area A: EAST TIB HENG & 1 & 1 & 1.00 \\
Area D: DZUN & 2 & 2 & 1.00 \\
Area B: EAST HIM & 1 & 2 & 0.50 \\
Area C: WEST HIM & 1 & 2 & 0.50 \\
Area E: SEM-AR MOUN & 1 & 3 & 0.33 \\
Area F: SE MED COAST & 1 & 3 & 0.33 \\
Area G: TAUR MOUN & 1 & 3 & 0.33 \\
Area H: SOUTH BALK PEN & 1 & 3 & 0.33 \\
\hline
\end{tabular}

only B. orphanidis (and 27 genera of Sapindales compared to 85 included here). Our study now provides strong support for the monophyly of Biebersteinia and its inclusion in Sapindales (with generally 100 bootstrap support and posterior probability, PP; Figs. 2 and 5). Based on the combined two genes, Bayesian and ML analyses weakly suggest that Biebersteinia may be sister to the remainder of Sapindales (97 PP, Fig. 5).

The placement of Biebersteinia in Sapindales, rather than Geraniales, agrees with the flavonoid composition of $B$. orphanidis, which resembles that of Rutaceae in certain uncommon methylated flavones, including sudachitin (Greenham et al. 2001). The flavonoid profile of $B$. orphanidis differs from the profiles of the central Asian species B. odora and B. heterostemon in containing six closely related flavone methyl ethers, with dihydroxy, dimethoxy A-ring substitution (Greenham et al. 2001). Also, fatty acids in $B$. orphanidis leaves are of the $C_{18: 3}$ type, a type not found in Geraniacae, but present in Sapindaceae (Tzakou et al. 2001). An investigation of the flower structure of Biebersteinia, in particular the type of nectaries, an important distinguishing feature of Sapindales, is currently in progress (Smets et al., in preparation).

Biogeography of Biebersteiniaceae. Our results imply that the eastern Tibetan plateau including the Hengduan Mountains, Dzungaria and western Tien Shan were part of the ancestral area of Biebersteiniaceae, and that the family diversified in the Oligocene and Miocene (Figs. 3 and 4, Tables 2 and 4). Both ancestral area analyses and the topologies of our trees (Figs. 2-5) suggest that early-branching Biebersteinia clades occurred in the eastern and western Himalaya, Karakoram, Pamir, Tien Shan, Alatau, and Altai mountain ranges. The Late Paleocene pollen fossils of $B$. heterostemon in the Neomugen Formation may indicate that Inner Mongolia was occupied even earlier. Biebersteinia then seems to have extended its range westwards to the mountains of Peloponnisos in the southern Balkan Peninsula. The sister species $B$. multifida and $B$. orphanidis have adjacent geographic ranges that meet where 


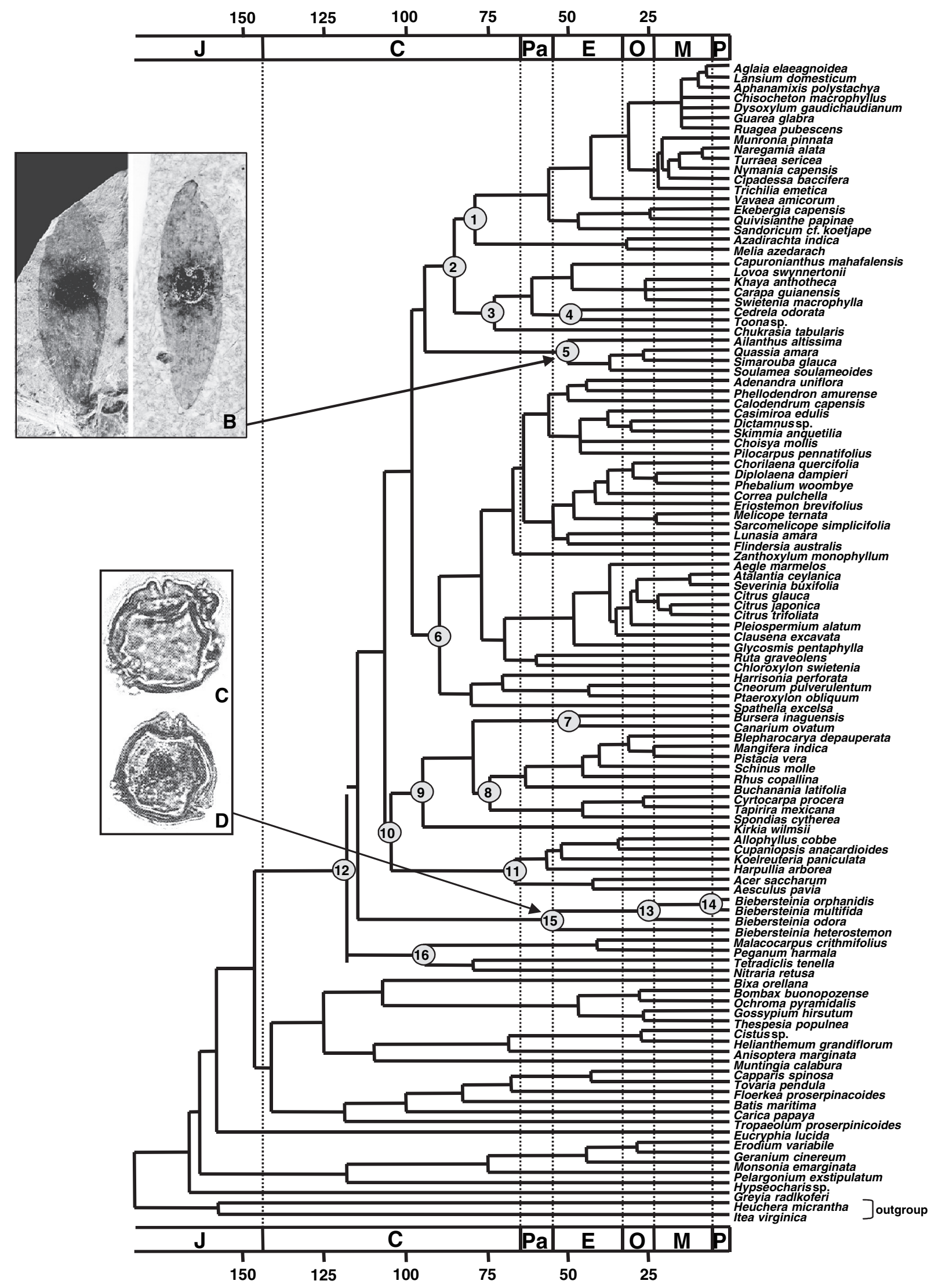


A. N. Muellner et al.: Biebersteinia and Sapindales

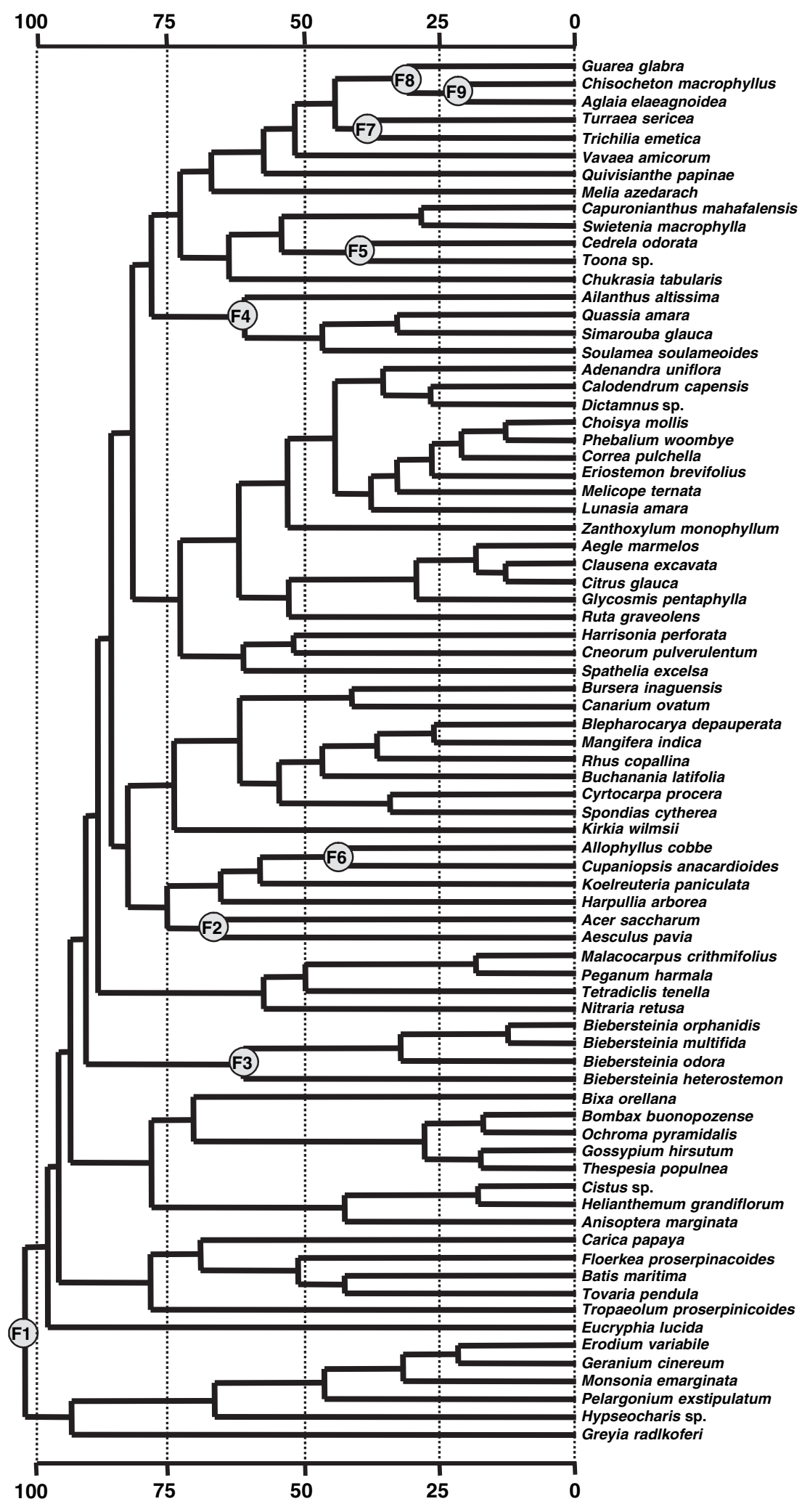


Fig. 4. Bayesian chronogram based on a maximum likelihood tree obtained from $r b c \mathrm{~L}$ sequences of 78 ingroup and two outgroup taxa. Nodes labelled F1-F9 refer to the position of fossils used to constrain the relaxed clock (see text for details). Numbers along the bars indicate million years

the Irano-Turanian floristic province changes to the Mediterranean province (Takhtajan 1986). While all Biebersteinia species are perennials, only these two have tuberous rhizomes, while the ancestral condition appears to be scarcely thickened roots. Biebersteinia odora differs from the other three species in being adapted to alpine conditions, frequently growing above 4500 $\mathrm{m}$ near glaciers. The fruits of the four species of Biebersteinia differ in the way they are attached to the receptacle, but without knowing the fruit morphology of the closest relatives the evolutionary direction of character change cannot yet be inferred.

The divergence time estimates for the crown group of Biebersteiniaceae obtained with NPRS (Table 2) are in good agreement with the Biebersteinia pollen fossil (when this is not used as a constraint). The Biebersteiniaceae stem lineage appears to date back at least to the Late Paleocene, if not the Early Paleocene (Table 2), thus predating the collision of India with southern Asia and the uplift of large mountain chains and plateaus (Barron and Harrison 1980, Summerfield 1991, Lee and Lawver 1995, McLoughlin 2001). Further diversification then took place in the Oligocene and Miocene. Given the long stem lineage and the small number of extant species, it is extremely likely that Biebersteinia has suffered much extinction. However, it is precisely the small size of the clade that prevents a lineage-through-time analysis, which might otherwise permit estimating levels of extinction.

The ranges of the four species of Biebersteinia exhibit several disjunctions. The Mediterranean species $B$. orphanidis is disjunct across the Aegean Sea, in mountains of southern Greece and Turkey. The alpine species B. odora (above) is known from the Karakorum Mts., Pamir Mts., Ala Tau, the
Tien Shan and the Altai Mts. to the north, but has not been collected in Nepal (Mark Watson, Royal Botanic Garden Edinburgh, personal communication, 2006) nor is it known from Bhutan (Grierson and Long 1987). The species re-appears in the eastern Himalaya, in the region of Shugden Gompa, where Kingdon-Ward collected it in 1933 (deposited in the herbarium BM, seen by DV). The range of $B$. heterostemon extends from the eastern and north-eastern part of the Tibetan plateau south to the Hengduan Mountains, to the east and to the north of the Brahmaputra river, which separates it from B. odora (except for the apparently isolated population of the latter near Shugden Gompa). The Brahmaputra, known as the Yarlong Tsangpo in its upper reaches, also is a biogeographic barrier in other plant groups, e.g. in Roscoea (Ngamriabsakul et al. 2000), Morinaceae (Bell et al. 2003), and Pleione (Gravendeel et al. 2005), as well as for elephants (Vidya et al. 2005).

Sapindalean clades ranked as families much older than previously assumed. To provide an "initial hypothesis of angiosperm diversification times," Wikström et al. (2001) used a tree from a three-gene phylogenetic analysis by Soltis et al. (1999, 2000) that included 560 angiosperms and seven outgroup taxa, representing ca. $75 \%$ of the angiosperm families (APG 1998), and applied NPRS with a single fossil-based constraint, namely the divergence of Fagales from Cucurbitales based on the occurrence of Protofagacea and Antiquacupula in the Campanian and Late Santonian of Georgia. Their dataset included five genera of Sapindaceae, one genus (Ailanthus) of Simaroubaceae, two of Meliaceae, three of Rutaceae, and one genus each of Burseraceae (Bursera) and Anacardiaceae (Schinus). Taxon sampling affects age estimates, with sparse sampling leading to 


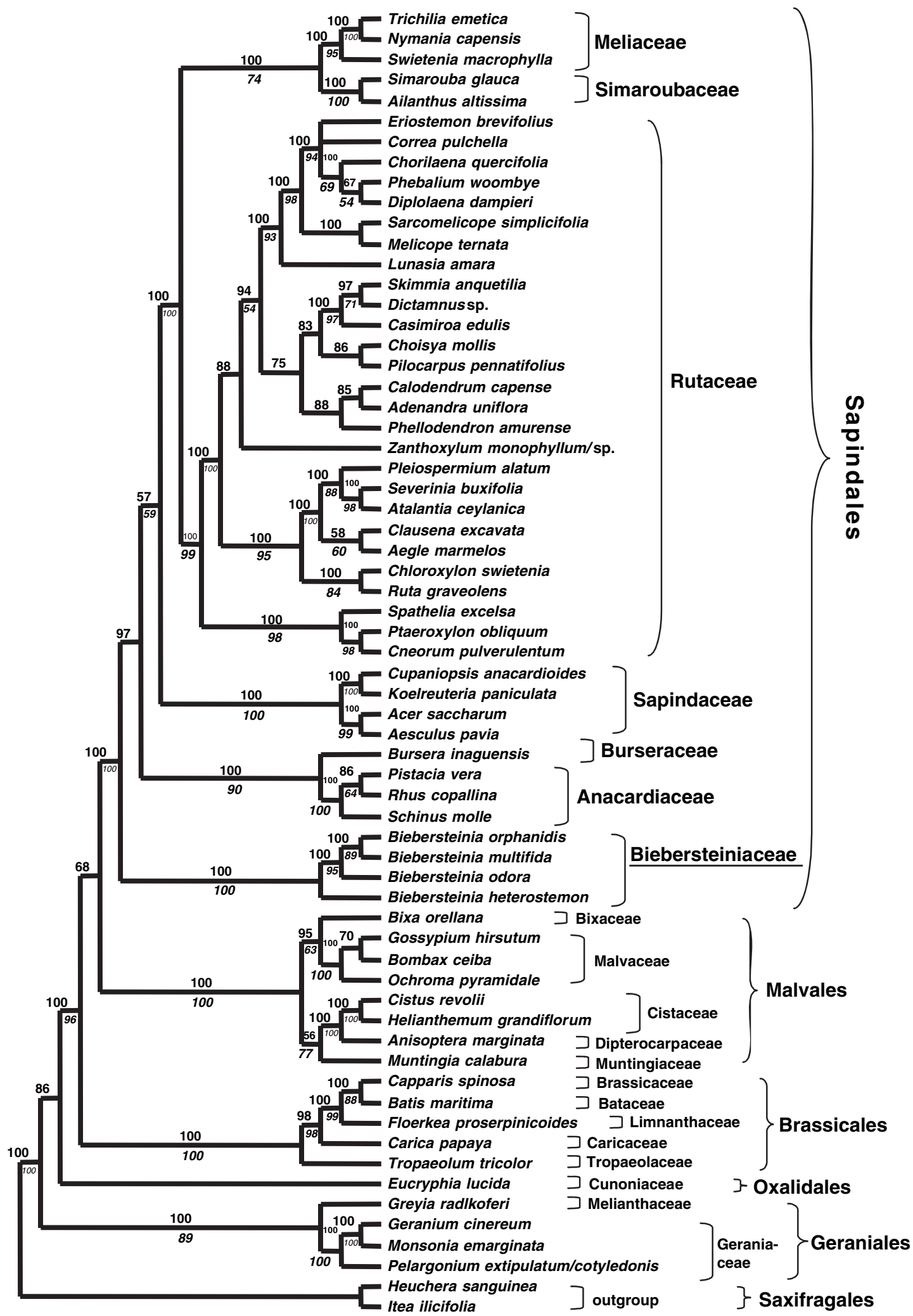


Fig. 5. Bayesian tree obtained from combined $r b c \mathrm{~L}$ and $a t p \mathrm{~B}$ sequences of 62 ingroup and two outgroup taxa. Numbers above branches are Bayesian posterior probabilities, numbers below branches are bootstrap values (1000 replicates; italicized). Families and orders after APG II (2003)

younger ages than denser sampling (Sanderson et al. 2004, Linder et al. 2005). This is borne out by a comparison of the ages obtained here with a sample of 85 genera with those in Wikström et al. (2001) with a sample of 13 genera. Estimates differ by $50 \%$ and more, for example, the minimum age of the Meliaceae crown group in Wikström et al. was $36 \mathrm{my}$, while we obtained an age of ca. 85 my (likewise for Rutaceae 38 my versus ca. 90 my; Sapindales 62 my versus ca. 120 my; Table 2). For Burseraceae, by contrast, all studies so far yield similar ages. Wikström et al. (2001) estimated the Burseraceae crown group age as $52 \pm 5 \mathrm{my}$, based on three genes and one species of Burseraceae (including representatives of six families of Sapindales); Weeks et al. (2005) estimated it as $60 \pm 1.9 \mathrm{my}$, based on two genes from 50 species representing 13 genera of Burseraceae (including two families of Sapindales); and we obtained ages of 56.3 my (strict clock), $48.1 \pm 9.3 \mathrm{my}(\mathrm{NPRS})$, or $41.4 \mathrm{my}$ (c.i. = 20.2-65.2; Bayesian clock), based on one gene and two species from as many genera (including representatives of all nine families of Sapindales). These and other molecular dating results highlight the need for dense taxon sampling as well as the importance of checking results against other types of evidence if time estimates are to be trusted. Sapindales, with their rich fossil record, provide an exceptional system for comparing different clock approaches because they permit such critical cross-validation.

We thank E. Kapinos (Kew) and H. Henselewski (Frankfurt) for help in the lab; F. Bakker (Wageningen) for his $a t p \mathrm{~B}$ data matrix; V. Holubec (Prague) for material of B. odora; D. E. Boufford (Harvard) for material of $B$. heterostemon through the NSF grant DEB-0321846; W.-M. Wang (Nanjing) for images of fossil pollen of B. heterostemon from the Neomugen Formation, and M. Watson (Edinburgh) and N. Turland (Saint Louis) for information on the distribution of Biebersteinia. Financial support for this study was provided by an EU Marie Curie Fellowship to ANM (MEIFCT-2003-502194), and the Research Institute Senckenberg.

\section{References}

APG [Angiosperm Phylogeny Group] (1998) An ordinal classification for the families of flowering plants. Ann. Missouri Bot. Gard. 85: 531553.

APG II. (2003) An update of the Angiosperm Phylogeny Group classification for the orders and families of flowering plants: APG II. Bot. J. Linn. Soc. 141: 399-436.

Bakker F. R., Vassiliades D. D., Morton C., Savolainen V. (1998) Phylogenetic relationships of Biebersteinia Stephan (Geraniaceae) inferred from $r b c \mathrm{~L}$ and $a t p \mathrm{~B}$ sequence comparisons. Bot. J. Linn. Soc. 127: 149-158.

Barron E. J., Harrison C. G. A. (1980) An analysis of past plate motions; the South Atlantic and Indian oceans. In: Davies P. A., Runcorn S. K. (eds.) Mechanisms of continental drift and plate tectonics. Academic Press, London, pp. 89-109.

Bell C. D., Donoghue M. J. (2003) Phylogeny and biogeography of Morinaceae (Dipsacales) based on nuclear and chloroplast DNA sequences. Org. Divers. Evol. 3: 227-237.

Boissier E. (1867) Biebersteiniae. In: Flora Orientalis Vol. 1. H. Georg, Basilee, pp. 899-900.

Bremer K. (1992) Ancestral areas: a cladistic reinterpretation of the center of origin concept. Syst. Biol. 41: 436-445.

Brenner G. J. (1996) Evidence for the earliest stage of angiosperm pollen evolution: A paleoequatorial section from Israel. In: Taylor D. W., Hickey L. J. (eds.) Flowering plant origin, evolution and phylogeny. Chapman and Hall, New York, pp. 91-115.

Chase M. W., Morton C. M., Kallunki J. A. (1999) Phylogenetic relationships of Rutaceae: a cladis- 
tic analysis of the subfamilies using evidence from $r b c \mathrm{~L}$ and $a t p \mathrm{~B}$ sequence variation. Amer. $\mathrm{J}$. Bot. 86, 1191-1199.

Corbett S. L., Manchester S. R. (2004) Phytogeography and fossil history of Ailanthus (Simaroubaceae). Int. J. Pl. Sci. 165: 671-690.

DeVore M. L., Kenrick P., Pigg K. B., Ketcham R. A. (2005) CT-Scanning the London Clay: an excellent noninvasive technique for studying pyritized fossil fruits. Abstract 122, Botany 2005.

Doyle J. J., Doyle J. L. (1987) A rapid DNA isolation procedure from small quantities of fresh leaf tissue. Phytochem. Bull. 19: 11-15.

Endlicher S. L. (1841). Biebersteiniaceae. In: Enchiridion Botanicum. Leipzig.

Farsam H., Amanlou M., Reza Dehpour A., Jahaniani F. (2000) Anti-inflammatory and analgesic activity of Biebersteinia multifida DC. root extract. J. Ethnopharmacol. 71: 443-447.

Fay M. F., Bayer C., Alverson W., Bruijn A. Y. de, Swensen S. M., Chase M. W. (1998) Plastid $r b c$ L sequences indicate a close affinity between Diegodendron and Bixa. Taxon 47: 43-50.

Felsenstein J. (1985) Confidence limits on phylogenies: an approach using the bootstrap. Evolution 39: 783-791.

Fernando E. S., Gadek P. A., Quinn C. J. (1995) Simaroubaceae, an artificial construct: evidence from $r b c \mathrm{~L}$ sequence variation. Amer. J. Bot. 82: 92-103.

Fitch W. M. (1971) Toward defining the course of evolution: minimal change for a specific tree topology. Syst. Zool. 20: 406-416.

Ghosh P. K., Roy S. K. (1979) Chisochetonoxylon benegalensis gen. et sp. nov., a new fossil wood of Meliaceae from the Tertiary beds of Birbhum District, West Bengal, India. Curr. Sci. 48: 737-739.

Graham A., Jarzen D. M. (1969) Studies in Neotropical paleobotany. I. The Oligocene communities of Puerto Rico. Ann. Missouri Bot. Gard. 56: 308-357.

Gravendeel B., Schuiteman A., de Vogel E. F. (2005) Molecular dating and vicariance analysis of Coelogyninae (Orchidaceae). In: Bakker F. T., Chatrou L. W., Gravendeel B., Pelser P. B. (eds.) Plant-level systematics, new perspectives on pattern \& process. Gantner Verlag, Liechtentstein, pp. 131-148.

Greenham J., Vassiliades D. D., Harborne J. B., Williams C. A., Eagles J., Grayer R. J., Veitch
N. C. (2001) A distinctive flavonoid chemistry for the anomalous genus Biebersteinia. Phytochemistry 56: 87-91.

Grierson A. J. C., Long D. G. (1987) Flora of Bhutan, vol 1, part 3. Royal Botanic Garden Edinburgh, Edinburgh.

Hoot S. B., Culham A., Crane P. R. (1995) The utility of atp B gene sequences in resolving phylogenetic relationships: Comparison within $r b c \mathrm{~L}$ and $18 \mathrm{~S}$ ribosomal DNA sequences in the Lardizabalaceae. Ann. Missouri Bot. Gard. 82: 194207.

Hughes N. F. (1994) The enigma of angiosperm origins. Cambridge Palaeobiology Series 1, Cambridge University Press, Cambridge.

Knuth R. (1912) Biebersteinia Steph. In: Engler A. (ed.) Das Pflanzenreich IV, Vol. 129. H. R. Engelmann, Berlin, pp. 546-549.

Lee T.-Y., Lawver L. A. (1995) Cenozoic plate reconstruction of the southeast Asia regions. Tectonophysics 251: 85-138.

Linder H. P., Hardy C. R., Rutschmann F. (2005) Taxon sampling effects in molecular clock dating: An example from the African Restionaceae. Molec. Phylogenet. Evol. 35: 569-582.

MacGinitie H. D. (1969) The Eocene Green River flora of northwestern Colorado and northeastern Utah. Univ. Calif. Publ. Geol. Sci. 83: 1-203.

MacGinitie, H. D. (1953) Fossil plants of the Florissant Beds, Colorado. Carnegie Institute of Washington, Publication 599, Washington, DC.

McClain, A. M., Manchester S. R. (2001) Dipteronia (Sapindaceae) from the Tertiary of North America and implications for the phytogeographic history of the Aceroideae. Amer. J. Bot. 88: 1316-1325.

McLoughlin S. (2001) The breakup history of Gondwana and its impact on pre-Cenozoic floristic provincialism. Austral. J. Bot. 49: 271300.

Miceli N., Taviano M. F., Tzakou O., Yannitsaros A., Vassiliades D., Giuffrida D., Galati E. M. (2005) Biebersteinia orphanidis Boiss. shows antioxidant and anti-inflammatory activity. Phcog. Mag. 1: 54-58.

Muellner A. N., Samuel R., Johnson S. A., Cheek M., Pennington T. D., Chase M. W. (2003) Molecular phylogenetics of Meliaceae based on nuclear and plastid DNA sequences. Amer. J. Bot. 90: 471-480.

Muellner A. N., Savolainen V., Samuel R., Chase M. W. (2006) The mahogany family "out-of- 
Africa": divergence time estimation, global biogeographic patterns inferred from plastid $r b c \mathrm{~L}$ DNA sequences, extant and fossil distribution of diversity. Molec. Phylogenet. Evol. 40: 236-250.

Ngamriabsakul C., Newman M. F., Cronk Q. C. B. (2000) Phylogeny and disjunction in Roscoea (Zingiberaceae). Edinb. J. Bot. 57: 39-61.

Olmstead R. G., Michaels H. J., Scott K. M., Palmer J. D. (1992) Monophyly of the Asteridae and identification of their major lineages inferred from DNA sequences of $r b c \mathrm{~L}$. Ann. Missouri Bot. Gard. 79: 249-265.

Palmer A. R., Geissman J. (1999) Geologic time scale. The Geological Society of America. Available at: www.geosociety.org/science/timescale/ timescl.pdf.

Posada D., Crandall K. A. (1998) Modeltest: testing the model of DNA substitution. Bioinformatics 14: 817-818.

Rambaut A., Charleston M. (2000) Phylogenetic Tree Editor v1.0 alpha 4-61. http://evolve. zoo.ox.ac.uk/software/TreeEdit.

Reid E. M. Chandler M. E. J. (1933) The London Clay Flora. British Museum (Natural History), London, UK.

Ronquist F. (1996) DIVA version 1.1. Computer program and manual available from Uppsala University (http://www.ebc.uu.se/systzoo/research/ diva/diva.html).

Ronquist F. (1997) Dispersal-vicariance analysis: a new approach to the quantification of historical biogeography. Syst. Biol. 46: 195-203.

Ronquist F., Huelsenbeck J. P. (2003) MrBayes 3: Bayesian phylogenetic inference under mixed models. Bioinformatics 19: 1572-1574.

Salamin N., Chase M. W., Hodkinson T. R., Savolainen V. (2003) Assessing internal support with large phylogenetic DNA matrices. Molec. Phylogenet. Evol. 27: 528-539.

Sanderson M. J. (1997) A nonparametric approach to estimating divergence times in the absence of rate constancy. Molec. Biol. Evol. 14: 1218-1232.

Sanderson M. J. (1998) Estimating rate and time in molecular phylogenies: beyond the molecular clock? In: Soltis D. E., Soltis P. S., Doyle J. J. (eds.) Molecular systematics of plants II: DNA sequencing, Kluwer, Boston, Massachusetts, USA, pp. 242-264.
Sanderson M. J., Donoghue M. J., Piel W. H., Eriksson T. (1994) TreeBASE: A prototype database of phylogenetic analyses and an interactive tool for browsing the phylogeny of life. Amer. J. Bot. 81: 183.

Sanderson M. J., Thorne J. L., Wikström N., Bremer K. (2004) Molecular evidence on plant divergence times. Amer. J. Bot. 91: 1656-1665.

Schönbeck-Temesy E. (1970) Geraniaceae: Biebersteinia. In: Rechinger K. H. (ed.) Flora Iranica. Akademische Druck- u. Verlagsanstalt, Graz, pp. 63-64.

Soltis P. S., Soltis D. E., Chase M. W. (1999) Angiosperm phylogeny inferred from multiple genes: a research tool for comparative biology. Nature: 402-404.

Soltis D. E. et al. (2000) Angiosperm phylogeny inferred from a combined dataset of $18 \mathrm{~S}$ rDNA, $r b c \mathrm{~L}$, and $a t p \mathrm{~B}$ sequences. Bot. J. Linn. Soc. 133: 381-461.

Song Z.-C., Wang W.-M., Fei H. (2004) Fossil pollen records of extant angiosperms in China. Bot. Rev. 70: 425-458.

Stamatakis A. (2006) RAxML-VI-HPC: Maximum likelihood-based phylogenetic analyses with thousands of taxa and mixed models. Bioinformatics 22: 2688-2690.

Stephan F. (1806) Déscription de deux nouveaux genres de plantes. Mém. Soc. Nat. Mosc. 1: 125-128.

Swofford D. L. (2002) PAUP*: phylogenetic analysis using parsimony (*and other methods), version 4, Sinauer Associates, Sunderland, Massachusetts, USA.

Summerfield M. A. (1991) Global geomorphology. Prentice Hall, USA, pp. 71-72.

Takhtajan A. (1986) Floristic regions of the world. University of California Press, Berkeley Los Angeles.

Takhtajan A. (1997) Diversity and classification of flowering plants. Columbia University Press, New York.

Thorne J. L., Kishino H (2002) Divergence time estimation and rate evolution with multilocus data sets. Syst. Biol. 51: 689-702.

Tzakou O., Yannitsaros A., Vassiliades D. (2001) Investigation of the $C_{16: 3} / C_{18: 3}$ fatty acid balance in leaf tissues of Biebersteinia orphanidis Boiss. (Biebersteiniaceae). Biochem. Syst. Ecol. 29: 765-767. 
Vassiliades D., Yannitsaros A. (2000) Orphanides's best discovery. Bot. Chron. 13: 241-248.

Vidya T. N. C., Fernando P., Melnick D. J., Sukumar R. (2005) Population genetic structure and conservation of Asian elephants (Elephas maximus) across India. Animal Conservation 8: 377-388.

Weeks A., Daly D. C., Simpson B. B. (2005) The phylogenetic history and biogeography of the frankincense and myrrh family (Burseraceae) based on nuclear and chloroplast sequence data. Molec. Phylogenet. Evol. 35: 85-101.

Wikström N., Savolainen V., Chase M. W. (2001) Evolution of the angiosperms: calibrating the family tree. Proc. Roy. Soc. Lond. B 268: 22112220.

Yang Z. (1997) PAML: a program package for phylogenetic analysis by maximum likelihood. Comp. Appl. BioSci. 13: 555-556 http://abacus. gene.ucl.ac.uk/software/paml.html ).
Zhang X. F., Hu B. L., Zhou B. N. (1995) Studies on the active constituents of Tibetan herb Biebersteinia heterostemon Maxim. Acta Pharmaceutica Sin. 30: 211-214.

Addresses of the authors: Alexandra N. Muellner (e-mail: alexandra.muellner@senckenberg.de), Molecular Systematics Section, Jodrell Laboratory, Royal Botanic Gardens Kew, Richmond, Surrey TW9 3DS, United Kingdom; current address: Department of Botany and Molecular Evolution, Grunelius-Moellgaard Laboratory, Research Institute Senckenberg, Senckenberganlage 25, 60325 Frankfurt, Germany. Dionyssios D. Vassiliades, 24 Issiodou St, 10674 Athens, Greece. Susanne S. Renner, Department of Biology, University of Munich, Menzinger-Str. 67, 80638 Munich, Germany. 